\title{
IMPACT OF HARVESTING TIMES ON CHEMICAL COMPOSITION AND METHANE PRODUCTIVITY OF SORGHUM (SORGHUM BICOLOR MOENCH L.)
}

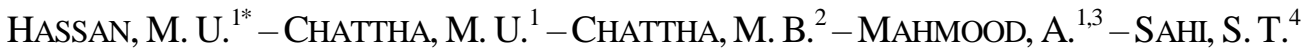 \\ ${ }^{1}$ Department of Agronomy, University of Agriculture, Faisalabad, Pakistan \\ ${ }^{2}$ Institute of Agricultural Sciences, University of the Punjab, Lahore, Pakistan \\ ${ }^{3}$ Punjab Bio-energy Institute (PBI), University of the Agriculture, Faisalabad, Pakistan \\ ${ }^{4}$ Department of Plant Pathology, University of the Agriculture, Faisalabad, Pakistan \\ *Corresponding author \\ e-mail: umer1379@gmail.com; +92-343-790-2494 \\ (Received $17^{\text {th }}$ Nov 2017; accepted $13^{\text {th }}$ Mar 2018)
}

\begin{abstract}
A two-year field study was conducted during 2016 and 2017 to determine the influence of harvesting times on biomass yield, quality and bio-methane yield of sorghum. Harvesting times considerably influenced the growth attributes, biomass quality and bio-methane yield. The maximum plant height, and dry matter (DM) yield were recorded 105 DAS, whilst lowest values of these parameters were recorded 60 DAS. Similarly, the maximum protein and sugar concentration were found 60 days after sowing (DAS), after that a substantial reduction in protein and sugar concentration were found with advancing maturity. Moreover, the highest acid and neutral detergent fiber, lignin, cellulose and hemicellulose were found 120 DAS whereas; minimum acid detergent fiber, neutral detergent fiber, lignin, cellulose and hemi-cellulose were observed 60 DAS. Likewise, maximum specific methane yield was recorded 60 DAS, while minimum specific methane yield were recorded 120 DAS, conversely, maximum methane yield ha ${ }^{-1}$ were recorded after 105 DAS owing to higher dry matter yield ha ${ }^{-1}$. Interestingly, we also found strong positive correlation between dry matter yield and methane yield and negative relationship between lignin concentrations and specific methane yield. In conclusion, sorghum crop can be harvested after, 105 DAS owing to high dry matter yield ha ${ }^{-1}$ for maximizing its potential for biomethane yield.
\end{abstract}

Keywords: harvesting time, biomass yield, sorghum, biomass quality, methane yield

\section{Introduction}

Energy is essential for substantial growth and development of nations; in addition, energy security and resource scarcity are key issues globally. The depletion of fossil fuels and increase in the green house gases due to combustion of fossil fuels has promoted the interest of environmentalists and policy makers for alternate energy sources (Monti et al., 2012). Amongst the alternate energy sources plant biomass is considered to be a sustainable and cheap source. Moreover, the plant biomass could cater the abovementioned problems. Energy crops are imperative biomass sources which can be used for the production of bio-energy. Among energy crops, sorghum is an indispensible crop cultivated globally for the production of bio-methane. Variety of attributes including, low water requirement, salinity and drought tolerance (Vasilakoglou et al., 2011; Hassan et al., 2018a), short growth period and well adoptability in arid and semi-arid regions (Reddy and Sanjana, 2003) makes it a promising bio-energy crop. Moreover, sorghum crop can efficiently transfer the available water into dry matter production than the other $\mathrm{C}_{4}$ crops (Dercas and Liakatas, 2007). 
Together with productivity, the quality of the biomass is important to bio-fuel conversion production systems. The quality of the produced can be optimized by just selecting the optimum harvesting time. Stage of harvesting is an imperative factor which substantially influences the biomass yield, chemical composition as well as biomass digestibility (Ball et al., 2001). The variations in biomass composition and yield have been reported owing to cultivar, environment and harvesting stage (Pordesimo et al., 2005; Hassan et al., 2018b). Prolonged maturity enhances the structural fiber and lignin concentrations and decreases biomass digestibility (Pordesimo et al., 2005) and consequently the bio-methane yield. The most common changes linked with harvesting time are biomass yield (Ayub et al., 2003), biomass quality i.e. protein concentrations, structural fiber and lignin concentrations and biomass digestibility and its conversion to bio-energy (Schittenhelm, 2008). So far, in Pakistan most of the research on sorghum has been focused on its fodder production aspects. There is no report available regarding the effect of harvesting time on chemical composition and biomass yield in the context of methane production. Therefore, this study was planned to determine the influence of harvesting times on biomass yield, chemical composition and bio-methane yield.

\section{Materials and methods}

\section{Study site}

A field study was conducted during 2016 and 2017 at Post Graduate Agriculture Research (PARS), University of Agriculture, Faisalabad, Pakistan. The study site comes under a sub-tropical climate, with a mean temperature of $27-39{ }^{\circ} \mathrm{C}$ during summer season and 6-21 ${ }^{\circ} \mathrm{C}$ during winter season (Chattha et al., 2017a). Furthermore, the prevailed climatic conditions during both the years are given in Table 1. The soil samples were collected before sowing crop in each season, and were analyzed by standard procedures of Homer and Pratt (1961). The soil was sandy loam and averagely the soil had a pH of 7.95 , Ec (1.2), organic matter (0.89\%), nitrogen $(0.03 \%)$ phosphorus $(6.43 \mathrm{ppm})$ and potassium $(186 \mathrm{ppm})$ respectively.

Table 1. Prevailing climatic conditions for the experimental site during year 2016 and 2017

\begin{tabular}{c|c|c|c|c|c|c|c|c|c|c}
\hline \multirow{2}{*}{ Months } & \multicolumn{2}{|c|}{$\begin{array}{c}\text { Monthly mean } \\
\text { maximum } \\
\text { temperature }\left({ }^{\circ} \mathbf{C}\right)\end{array}$} & \multicolumn{2}{|c|}{$\begin{array}{c}\text { Monthly mean } \\
\text { minimum } \\
\text { temperature }\left({ }^{\circ} \mathbf{C}\right)\end{array}$} & \multicolumn{2}{|c|}{$\begin{array}{c}\text { Monthly average } \\
\text { temperature }\left({ }^{\circ} \mathbf{C}\right)\end{array}$} & \multicolumn{2}{|c|}{ Rainfall (mm) } & \multicolumn{2}{|c}{$\begin{array}{c}\text { Relative } \\
\text { humidity }(\%)\end{array}$} \\
\cline { 2 - 12 } & $\mathbf{2 0 1 6}$ & $\mathbf{2 0 1 7}$ & $\mathbf{2 0 1 6}$ & $\mathbf{2 0 1 7}$ & $\mathbf{2 0 1 6}$ & $\mathbf{2 0 1 7}$ & $\mathbf{2 0 1 6}$ & $\mathbf{2 0 1 7}$ & $\mathbf{2 0 1 6}$ & $\mathbf{2 0 1 7}$ \\
\hline May & 39.8 & 41.1 & 25.6 & 26 & 32.7 & 33.5 & 25 & 10.1 & 28.8 & 29.8 \\
June & 40.2 & 39.8 & 28.5 & 27.3 & 34.4 & 33.5 & 39.9 & 41.6 & 38.9 & 44.5 \\
July & 36.6 & 38.5 & 27.4 & 28.9 & 32 & 33.7 & 193.5 & 161.4 & 59.6 & 70 \\
August & 35.7 & 38.1 & 26.5 & 28.6 & 31.1 & 33.4 & 48.1 & 66 & 62.2 & 68.9 \\
\hline
\end{tabular}

\section{Experimental design and crop cultivation}

The experiment was composed of five harvesting times i.e. 60, 75, 90, 105 and 120 days of sowing and a randomized complete block design with three replications were used for study. The final seed bed was prepared by ploughing three times followed by planking. The net plot size was $5 \mathrm{~m} \times 3 \mathrm{~m}$. In both years, nitrogen $(\mathrm{N})$ as urea $(46 \%$ N) $60 \mathrm{~kg} \mathrm{ha}^{-1}$ was applied, while phosphorus as single super phosphate $(21 \% \mathrm{P})$ 
$40 \mathrm{~kg} \mathrm{ha}^{-1}$ was applied. The sorghum variety YS-2016 was collected from Fodder Research Institute Faisalabad. The sorghum variety YS-2016 is late maturing. All the P and half of $\mathrm{N}$ were applied at the sowing, while rest of the $\mathrm{N}$ was applied with first irrigation. The crop was sown on $2^{\text {nd }}$ May and $6^{\text {th }}$ May during the year 2016 and 2017 respectively. In total three irrigations were applied during both the years. First irrigation was applied as soaking irrigation, second irrigation was applied 35 days after sowing and third irrigation was applied 68 days after sowing. All other management practices were kept normal and uniform during both years for good stand establishment.

\section{Sampling and measurements}

Ten plants were selected at each harvesting time in order to determine the plant height, leaves per plant, stem diameter, fresh and dry weights per plant. Moreover, the whole plots were harvested and dried to determine the biomass yield and later on mathematically converted to tones per hectare basis.

\section{Biomass analysis}

The samples for chemical analysis were oven dried, ground and sieved through $1 \mathrm{~mm}$ mesh screen. The concentrations of protein and ash were determined according to the AOAC (1990). Sugar, acid detergent fiber (ADF), neutral detergent fiber (NDF) and lignin concentrations (\% DM) were determined according to Dubois et al. (1956), Georing and Van-Soest (1970) and Van-Soest et al. (1991). Methane measurement was taken using Bioprocess Control's AMPTS equipment. Liquid manure was used a source of bacteria in order to anaerobically digest the sorghum sample. The $16 \mathrm{~g}$ of substrate was used in each digester after that the total volume of digesters were made up to $400 \mathrm{ml}$. Afterwards, digesters were perched with nitrogen gas in order to create the anaerobic conditions. The temperature of digesters was kept at $37{ }^{\circ} \mathrm{C}$ by standing them in water bath. The samples were allowed to digest for 28 days, in laboratory. The methane produced by each sample on every day was recorded from computer operated systems. At the end by using the amount of volatile solids the quantity of specific methane produced by each sorghum sample was calculated. Later on the specific methane produced by each sample was converted into hectare basis mathematically.

\section{Statistical analysis}

The collected data were analyzed by computer software Statistix 8.1 and least significant difference test was used to compare the treatments means at 5\% probability level (Steel et al., 1997). The graphs were generated by using Sigma plot software 9.

\section{Results}

The results revealed that harvesting times had substantiated influence on the growth attributes of sorghum i.e. plant height, stem diameter and leaves per plant (Table 2). The plant height ranged between 164-212 cm in 2016 and $161-210 \mathrm{~cm}$ in 2017 . Plant height increased progressively and reached the maximum extent at 105 days after sowing (DAS), after that there was no increase observed in plant height. Similarly, the maximum stem diameter was observed when crop was harvested 105 DAS, whereas the minimum stem diameter was observed 60 DAS. Likewise, maximum leaves per plant 
was recorded after 60 DAS afterwards, a substantial reduction in leaves per plant were recorded with minimum leaves at 120 DAS (Table 2).

There were significant differences among the harvesting times for fresh weight per plant, dry weight per plant and dry matter yield (DM; Table 2). The maximum fresh weight and dry weight per plant were recorded 105 DAS, after that both fresh and dry weight per plant started declining, whereas the minimum fresh weight per plant and dry weight were recorded at 60 DAS. Similarly, the crop harvested 105 DAS produced maximum DM yield $\left(16.26 \mathrm{tha}^{-1}, 16 \mathrm{tha}^{-1}\right)$, followed by crop harvested after $120 \mathrm{DAS}$, while the minimum DM yield $\left(10.46 \mathrm{t} \mathrm{ha}^{-1}, 10.06 \mathrm{tha}^{-1}\right)$ were obtained at 60 DAS.

Table 2. Effect of harvesting times on growth and biomass characteristics of Sorghum bicolor

\begin{tabular}{|c|c|c|c|c|c|c|c|c|c|c|c|c|}
\hline \multirow{2}{*}{$\begin{array}{l}\text { Harvesting } \\
\text { times }\end{array}$} & \multicolumn{2}{|c|}{$\begin{array}{c}\text { Plant height } \\
\text { (cm) }\end{array}$} & \multicolumn{2}{|c|}{$\begin{array}{l}\text { Stem diameter } \\
(\mathbf{c m})\end{array}$} & \multicolumn{2}{|c|}{$\begin{array}{l}\text { Leaves per } \\
\text { plant }\end{array}$} & \multicolumn{2}{|c|}{$\begin{array}{c}\text { Fresh weight per } \\
\text { plant (g) }\end{array}$} & \multicolumn{2}{|c|}{$\begin{array}{l}\text { Dry weight per } \\
\text { plant }(\mathrm{g})\end{array}$} & \multicolumn{2}{|c|}{$\begin{array}{l}\text { DM yield } \\
\text { t ha }^{-1}\end{array}$} \\
\hline & 2016 & 2017 & 2016 & 2017 & 2016 & 2017 & 2016 & 2017 & 2016 & 2017 & 2016 & 2017 \\
\hline 60 DAS & $164 c$ & $161 \mathrm{c}$ & $1.03 \mathrm{c}$ & $1.01 \mathrm{c}$ & $15.13 \mathrm{a}$ & $14.60 \mathrm{a}$ & $133.33 d$ & $130.00 \mathrm{c}$ & $27.83 \mathrm{e}$ & $26.53 d$ & $10.46 \mathrm{~d}$ & $10.06 \mathrm{~d}$ \\
\hline 75 DAS & $184 b$ & $182 b$ & $1.09 \mathrm{bc}$ & $1.06 \mathrm{c}$ & $12.53 b$ & $12.16 \mathrm{~b}$ & $149.67 \mathrm{~cd}$ & $145.33 c$ & $34.66 \mathrm{~d}$ & $32.40 \mathrm{c}$ & $12.72 \mathrm{c}$ & $12.36 \mathrm{c}$ \\
\hline 90 DAS & $197 b$ & $199 a$ & $1.20 \mathrm{ab}$ & $1.18 \mathrm{~b}$ & $11.53 b$ & $11.16 \mathrm{~b}$ & $166.67 \mathrm{bc}$ & $163.00 \mathrm{~b}$ & $38.00 \mathrm{c}$ & $35.90 \mathrm{bc}$ & $14.73 b$ & $14.36 \mathrm{~b}$ \\
\hline 105DAS & $212 a$ & $210 \mathrm{a}$ & $1.33 \mathrm{a}$ & $1.30 \mathrm{a}$ & $9.80 \mathrm{c}$ & $9.56 c$ & $185.00 \mathrm{a}$ & $182.67 \mathrm{a}$ & $45.06 \mathrm{a}$ & $43.00 \mathrm{a}$ & $16.26 \mathrm{a}$ & $15.96 \mathrm{a}$ \\
\hline 120DAS & $212 a$ & $210 \mathrm{a}$ & $1.28 \mathrm{a}$ & $1.26 \mathrm{ab}$ & $8.03 \mathrm{~d}$ & $7.66 \mathrm{~d}$ & 177.33ab & $174.67 \mathrm{ab}$ & $41.06 \mathrm{~b}$ & 39.10ab & $16.13 \mathrm{a}$ & $15.80 \mathrm{a}$ \\
\hline $\begin{array}{c}\text { LSD } \\
(p \leq 0.05)\end{array}$ & 13.43 & 13.22 & 0.13 & 0.11 & 1.21 & 1.00 & 18.30 & 16.83 & 2.36 & 4.58 & 0.64 & 0.73 \\
\hline
\end{tabular}

Values sharing different letters differed at $\mathrm{p}<0.05$, DAS: days after sowing

There were considerable differences among the harvesting times for qualitative attributes (Table 3). The highest protein and sugar concentrations (\% DM) were obtained from the earliest harvesting (60 DAS), while lowest protein and sugar was obtained from latest harvesting (120 DAS). Moreover, the harvesting times also had considerable influence on the acid detergent fiber (ADF), neutral detergent fiber (NDF), lignin, cellulose and hemi-cellulose concentrations (\% DM) (Fig. 1). A linear increase in ADF, NDF, lignin, cellulose and hemi-cellulose were found with advancing maturity. The maximum $\mathrm{ADF}$ and NDF concentrations were recorded 120 DAS that was comparable with 105 DAS, whilst lowest ADF and NDF concentrations in plant biomass were recorded at 60 DAS (Fig. $1 a, b$ ). The highest lignin, cellulose and hemicellulose concentrations in plant biomass were recorded at 120 DAS that was comparable with 105 DAS, whilst, lowest lignin, cellulose and hemi-celluloses, were recorded 60 DAS among the harvesting times (Fig. 1c,d). Similarly, ash concentrations significantly decreased with maturity, with maximum ash concentration (10.53, $10.76 \%$ ) were observed 60 DAS, while lowest ash concentration $(7.63,7.80 \%)$ were recorded 120 DAS that was comparable with 105 DAS (Table 3). 

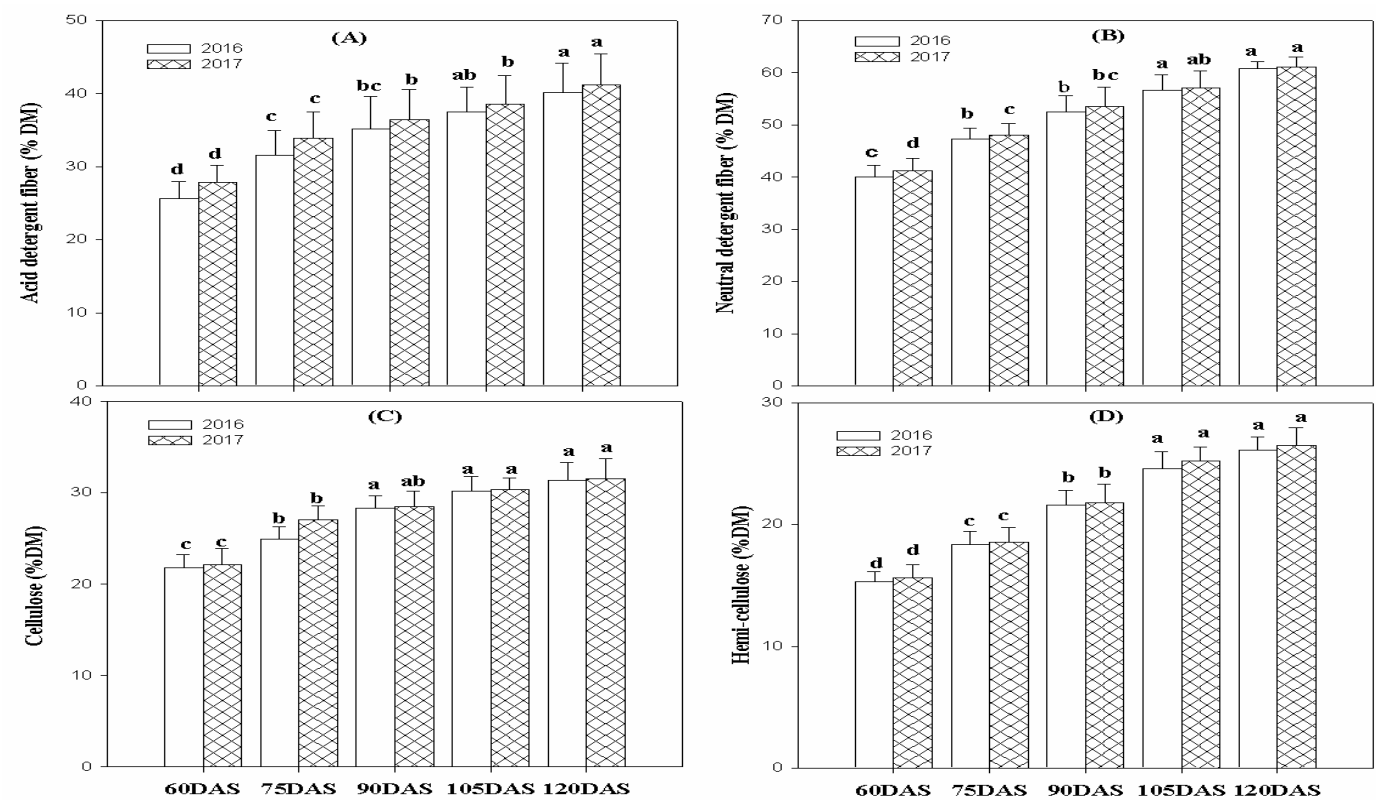

Figure 1. Influence of harvesting times on acid detergent fiber (A), neutral detergent fiber (B), cellulose $(C)$ and hemi-cellulose (D) concentration during the 2016 and 2017. Values represent means \pm S.D. The significant differences were measured by the least significant differences at 0.05 and indicated by different letters

Table 3. Effect of harvesting times on protein, sugar, lignin and ash concentration of sorghum bicolor

\begin{tabular}{c|c|c|c|c|c|c|c|c}
\hline \multirow{2}{*}{ Harvesting times } & \multicolumn{2}{|c|}{$\begin{array}{c}\text { Protein concentration } \\
\text { (DM \%) }\end{array}$} & $\begin{array}{c}\text { Sugar concentration } \\
\text { (DM \%) }\end{array}$ & $\begin{array}{c}\text { Lignin concentration } \\
\text { (DM \%) }\end{array}$ & \multicolumn{2}{c}{$\begin{array}{c}\text { Ash concentration } \\
\text { (DM \%) }\end{array}$} \\
\cline { 2 - 9 } & $\mathbf{2 0 1 6}$ & $\mathbf{2 0 1 7}$ & $\mathbf{2 0 1 6}$ & $\mathbf{2 0 1 7}$ & $\mathbf{2 0 1 6}$ & $\mathbf{2 0 1 7}$ & $\mathbf{2 0 1 6}$ & $\mathbf{2 0 1 7}$ \\
\hline $60 \mathrm{DAS}$ & $12.53 \mathrm{a}$ & $12.12 \mathrm{a}$ & $11.58 \mathrm{a}$ & $11.46 \mathrm{a}$ & $3.11 \mathrm{~d}$ & $3.24 \mathrm{~d}$ & $10.53 \mathrm{a}$ & $10.76 \mathrm{a}$ \\
$75 \mathrm{DAS}$ & $11.550 \mathrm{~b}$ & $11.47 \mathrm{ab}$ & $10.86 \mathrm{~b}$ & $10.14 \mathrm{~b}$ & $4.13 \mathrm{c}$ & $4.20 \mathrm{c}$ & $9.53 \mathrm{~b}$ & $9.64 \mathrm{~b}$ \\
$90 \mathrm{DAS}$ & $11.06 \mathrm{bc}$ & $10.93 \mathrm{bc}$ & $10.13 \mathrm{c}$ & $10.10 \mathrm{~b}$ & $5.11 \mathrm{~b}$ & $5.22 \mathrm{~b}$ & $8.57 \mathrm{c}$ & $8.69 \mathrm{c}$ \\
$105 \mathrm{DAS}$ & $10.33 \mathrm{~cd}$ & $10.26 \mathrm{~cd}$ & $9.96 \mathrm{c}$ & $9.41 \mathrm{bc}$ & $5.54 \mathrm{ab}$ & $5.59 \mathrm{ab}$ & $7.66 \mathrm{~d}$ & $7.86 \mathrm{~d}$ \\
$120 \mathrm{DAS}$ & $10.10 \mathrm{~d}$ & $10.02 \mathrm{~d}$ & $9.22 \mathrm{~d}$ & $9.14 \mathrm{c}$ & $5.76 \mathrm{a}$ & $5.85 \mathrm{a}$ & $7.63 \mathrm{~d}$ & $7.80 \mathrm{~d}$ \\
LSD $(p \leq 0.05)$ & 0.76 & 0.71 & 0.71 & 0.76 & 0.46 & 0.46 & 0.78 & 0.74 \\
\hline
\end{tabular}

Values sharing different letters differed at $\mathrm{p}<0.05$, DAS: days after sowing

The results revealed that harvesting times substantially influenced the specific methane yield and methane ha $^{-1}$ basis (Fig. 2). The specific methane yield (SMY) considerably decreased with advancing maturity, with maximum SMY were observed at 60 DAS, followed by 75 DAS, whilst lowest SMY were recorded at 120 DAS (Fig. 2a). Conversely, methane yield ha $^{-1}$ increased with advancing the maturity up to 105 DAS with maximum methane yield ha $^{-1}$ were recorded after 105 DAS, followed by 120 DAS, while lowest methane yield ha $^{-1}$ were recorded 60 DAS (Fig. 2b). We also observed the significant positive correlation between DM yield and methane yield during both the years (Fig. 3); an increase in DM yield appreciably increased the methane yield. Interestingly, a negative correlation was observed SMY and lignin concentrations (Fig. 4); it was found that increase in lignin concentrations substantially reduced the specific methane yield. 

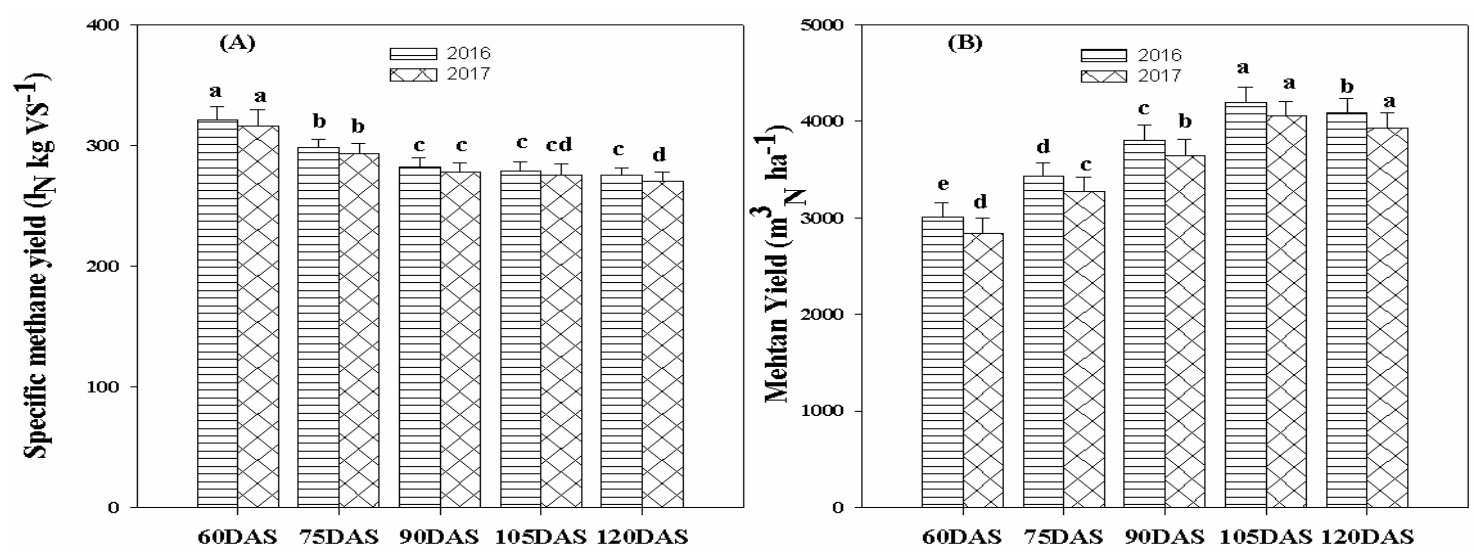

Figure 2. Influence of harvesting times on specific methane yield $(A)$ and methane yield ha $^{-1}$ basis (B) during the year 2016 and 2017. DAS: DAS: Days after sowing, Values represent means $\pm S . D$. The significant differences were measured by the least significant differences at 0.05 and indicated by different letters

(2016)

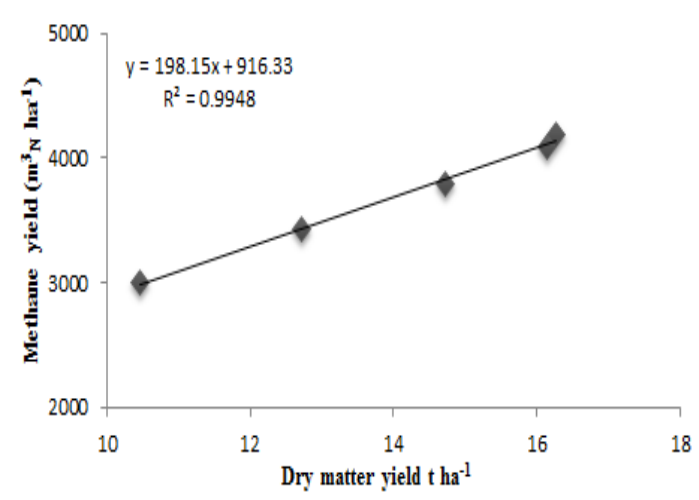

(2017)

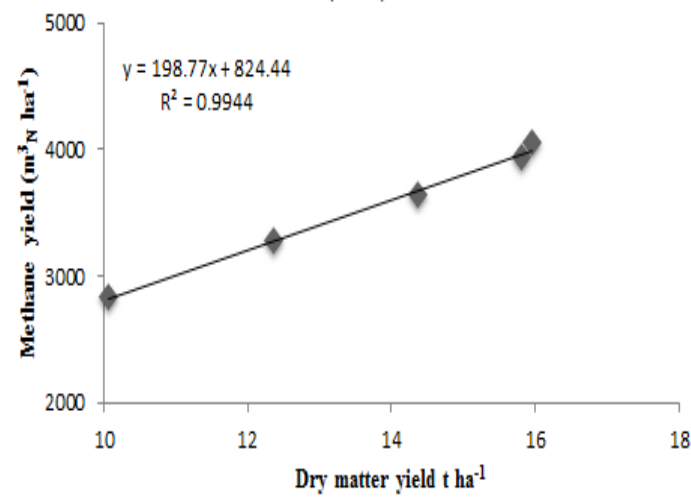

Figure 3. Relationship between dry matter yield $h a^{-1}$ and methane yield $m_{N}^{3}$ hal during 2016 and 2017

(2016)

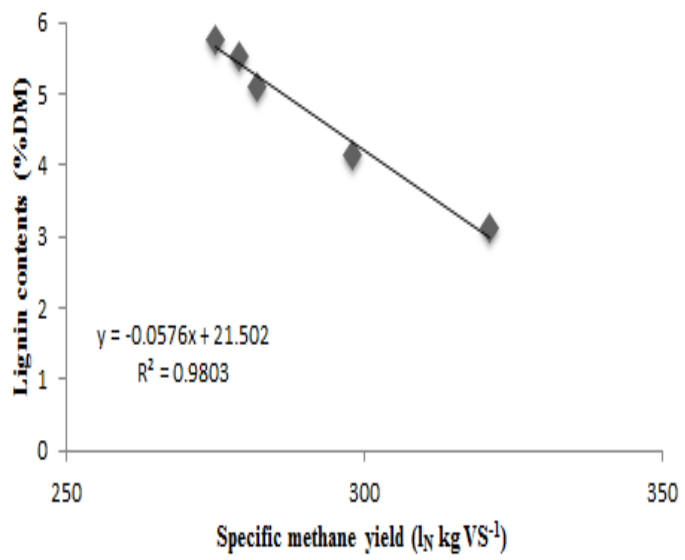

(2017)

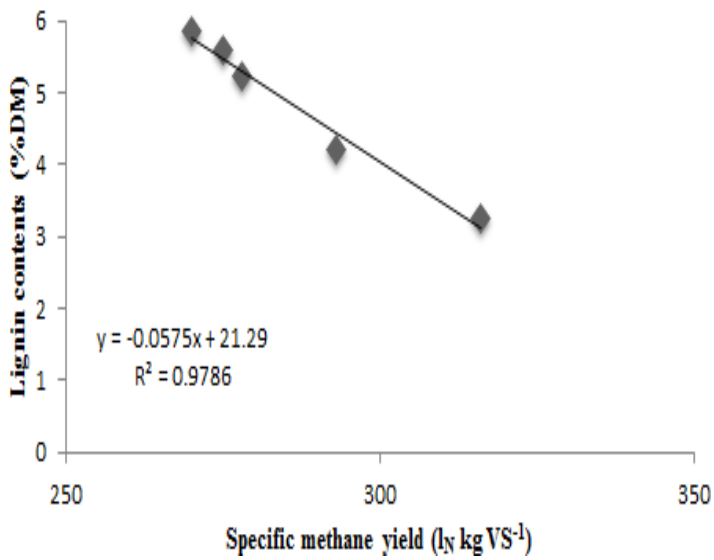

Figure 4. Relationship between specific methane yield $l_{N} \mathrm{~kg} \mathrm{VS}^{-1}$ and lignin concentration (\%DM) during 2016 and 2017 


\section{Discussion}

Results revealed that harvesting times significantly influenced the dry matter yield, biomass quality and bio-methane yield. The plant height increased with delaying the harvesting up to 105 days after sowing (DAS), afterwards, delay in harvesting had no significant effect on the plant owing to termination of stem elongation. These results are in consistence with earlier finding of Tariq et al. (2011), who also found the appreciable influence of harvesting times on plant height. Similarly, the maximum stem diameter was found 105 DAS that was due to continuous accumulation of fibrous compounds in central stem. Current findings are supported by Naeem et al. (2007) and Amodu et al. (2007) who also proved a significant effect of harvesting time on stem diameter. The DM yield positively increased with delaying maturity up to 105 DAS, afterwards a little bit reduction in DM yield was found. The lower DM yield at early stage can be ascribed to lower plant height and stem diameter, moreover, the maximum DM yield at 105 DAS was possibly due to maximum plant height and stem diameter. These results are in accordance with findings of Chattha et al. (2017b), Ram et al. (2007) and Hussain et al. (2002) who also reported the substantial increase in DM yield with advancing maturity. Nonetheless the reduction in DM yield after 105 DAS might be due to reduction in the availably of water soluble carbohydrates, more falling of leaves and initiation of plant senescence. The protein concentrations decreased positively with the passage of time with minimum protein concentration were found 120 DAS. Moreover, leaves are rich source of protein and stems are considered to be low in protein concentrations. Therefore, the reduction in protein concentrations with advancing maturity can also be due loss of leaves and increase in stem proportion. Other researchers also reported the considerable reduction in protein concentrations with advancing the maturity (Ayub et al., 2002; Butler and Muir, 2003). Similarly, the maximum sugar concentration was found at earlier harvesting and lowest sugar concentrations were found at later harvesting stage. We suppose that younger plants have more physiological activities, thus have more sugar production. These findings are corroborated with earlier results of Umer et al. (2017b) who also reported the considerable influence of harvesting times on the sugar concentrations. Similarly, structural fibers including ADF, NDF, cellulose, hemi-cellulose and lignin concentrations tended to increase, whereas the ash concentrations tended to decrease with advancing the maturity stage. The structural fibers including cellulose, hemi-cellulose and lignin are parts of secondary cell wall, and they appear during the formation and thickening of cell walls, therefore, cell wall thickening increases with maturity which in turn influences the structural fiber and lignin concentrations. Earlier researchers also reported structural fiber and lignin contents considerably increased with the advancing maturity (Filya, 2004; Carmi et al., 2005; Miron et al., 2006). The ash concentrations decreased with delayed harvesting owing to loss of plant leaves and translocation of inorganic nutrients form vegetative plant parts to reproductive parts. The considerable differences in ash concentrations with varying harvesting stages have also been documented by Kitaba and Tamir (2007).

We also reported the considerable influence of harvesting times on the specific methane yield and methane yield per hectare basis. The negative correlation between SMY and lignin concentration might be due to the reason that the higher lignin concentration decrease the digestibility of biomass and consequently decrease SYM and vice versa. The maximum SMY were reported 60 DAS, whereas, the minimum SMY were reported $120 \mathrm{DAS}$, conversely, maximum methane yield $\mathrm{ha}^{-1}$ were found 105 DAS, whereas the minimum were reported at 60 DAS (Table 2). The maximum SMY at 
60 DAS can be ascribed to lower lignin concentrations, because lower lignin concentrations resulted in earlier and better digestibly of dry matter which leads to higher specific methane yield. In addition, higher lignin concentrations substantially reduced the DM digestibility (Yosef et al., 2009) and ultimately the specific methane yield. Similarly, despite of the lower SMY at 105 DAS, the methane yield ha ${ }^{-1}$ increased due to higher dry matter production $\mathrm{ha}^{-1}$ basis.

\section{Conclusion}

Harvesting times had considerable influence on the biomass yield, biomass quality and bio-methane yield. Early harvesting produced the crop significantly lower in DM yield and also lower in structural fiber and lignin concentrations. Moreover, later harvesting produced the crop higher both in DM yield and structural fiber and lignin concentrations. Similarly, maximum SMY were recorded 60 DAS, however, it was over compensated by 105 DAS owing to higher dry yield ha ${ }^{-1}$. Conclusively, harvesting 105 DAS have advantage over the other harvesting times due to higher DM yield in order to get maximum methane yield $\mathrm{ha}^{-1}$. However, further studies are needed to include more cultivars to explore the effect of different harvesting times and other agronomic factors i.e. sowing times, planting geometry and locations on chemical composition and biomethane yield of sorghum under climatic conditions of Pakistan.

\section{REFERENCES}

[1] Amodu, J. T., Adeyinka, I. A., Kallah, M. S., Alawa, J. P. (2007): Evaluation of pearl millet accession for yield and nutrient composition. - Journal of Biological Sciences 7: 379-383.

[2] AOAC (1990): Official Methods of Analysis, 15th ed. - Association of Official Analytical Chemists, Virginia, USA.

[3] Ayub, M., Nadeem, M. A., Tanveer, A., Husnain, A. (2002): Effect of different levels of nitrogen and harvesting times on the growth, yield and quality of sorghum fodder. Asian Journal of Plant Sciences 1: 304-307.

[4] Ayub, M., Nadeem, M. A., Suleheri, M. J. (2003): Effect of harvesting times on maize fodder yield and quality. - Bangladesh Journal of Agriculture 27: 28: 71-75.

[5] Ball, D. M., Collins, M., Lacefield, G. D., Martin, N. P., Mertens, D. A., Olson, K. E., Putnam, D. H., Undersander, D. J., Wolf, M. W. (2001): Understanding Forage Quality. - American Farm Bureau Federation Publication, Park Ridge, Illinois, USA.

[6] Butler, T. J., Muir, J. P. (2003): Row Spacing and Maturity of Forage Sorghum Silage in North Central Texas. Forage Research in Texas. http://forageresearch.tamu.edu/2003/Forage Sorghum (accessed 27/3/2017).

[7] Carmi, A., Umiel, N., Hagiladi, A., Yosef, E., Ben-Ghedalia, D., Miron, J. (2005): Field performance and nutritive value of a new forage sorghum variety 'Pnina' recently developed in Israel. - Journal of Science of Food and Agriculture 85: 2567-2573.

[8] Chattha, M. U., Hassan, M. U., Khan, I., Chattha, M. B., Mahmood, A., Nawaz, M., Subhani, M. N., Kharal, M., Khan, S. (2017a): Biofortification of wheat cultivars to combat zinc deficiency. - Frontiers in Plant Sciences 8: 281. DOI: 10.3389/fpls.2017.00281.

[9] Chattha, M. U., Iqbal, A., Hassan, M. U., Ishaque, W., Usman, M., Khan, S., Fayyaz, M. T., Ullah, M. A. (2017b): Forage yield and quality of sweet sorghum as influenced by sowing methods and harvesting times. - Journal of Basic and Applied Sciences 13: 301-306. 
[10] Dercas, N., Liakatas, A. (2007): Water and radiation effect on sweet sorghum productivity. - Water Research Management 21: 1585-1600.

[11] Dubois, M., Gilles, K. A., Hamilton, J. K., Rebers, P. A., Sith, F. (1956): Calorimetric method for determination of sugars and related substances. - Analytical Chemistry 28: $350-356$.

[12] Filya, I. (2004): Nutritive value and aerobic stability of whole maize silage harvested at four stages of maturity. - Animal Feed Science and Technology 116: 141-150.

[13] Goering, M. K., Vansoest, P. J. (1970): Forage Fiber Analysis (Apparatus, Reagents, Procedures and Some Applications. - Agricultural Research Service, US Dept. of Agriculture, Washington, DC, USA.

[14] Hassan, M. U., Chatta, M. U., Mahmood, M. A., Sahi, S. T. (2018a): Performance of sorghum cultivars for biomass quality and bio-methane yield grown in semi arid area of Pakistan. - Environmental Science and Pollution Research 1574: 1-8.

[15] Hassan, M. U., Chatta, M. U., Chattha, M. B., Mahmood, M. A., Sahi, S. T. (2018b): Bio-methane production for sorghum elite lines under climatic conditions of Pakistan. Maydica 63: 1-8.

[16] Homer, D. C., Pratt, P. F. (1961): Methods of Analysis for Soils, Plants and Waters. University of California, Davis.

[17] Hussain, A., Khan, S., Mohammad, D. (2002): Forage yield and nutritive value of oat cultivar fatua at various intervals of harvesting. - Pakistan Journal of Agriculture Research 17: 148-152.

[18] Kitaba, A., Tamir, B. (2007): Effect of harvesting stage and nutrient levels on nutritive values of natural pasture in central high lands of Ethiopia. - Agriculture of Tropical and Subtropical 40(1): 7-12.

[19] Miron, J., Solomon, R., Adin, G., Nir, U., Nikbachat, M., Yosef, E., Carmi, A., Weinberg, Z. G., Kipnis, T., Zuckerman, E., Ben-Ghedalia, D. (2006): Effects of harvest stage and re-growth on yield, composition, ensilage and in vitro digestibility of new forage sorghum varieties. - Journal of Science of Food and Agriculture 86: 140147.

[20] Monti, A., Barbanti, L., Zatta, A., Zegadalizarazu, W. (2012): The contribution of switchgrass in reducing GHG Emissions. - Global Change Biology Bioenergy 4: 420434.

[21] Naeem, M., Chohan, M. S. M., Khan, A. H., Kainth, R. A. (2007): Performance of pearl millet genotypes for forage under irrigated conditions. - Journal of Agriculture Research 45: 199-203.

[22] Pordesimo, L. O., Hames, B. R., Sokhansanj, S., Edens, W. C. (2005): Variation in corn stover composition and energy content with crop maturity. - Biomass Bio-energy 28: 3 66-374.

[23] Ram, S. N., Suresh, G., Singh, K. K. (2007): Effect of planting geometry and cutting management on productivity, quality and economics of mixed pasture under rainfed conditions. - Indian Journal of Agronomy 52: 251-256.

[24] Reddy, B. V. S., Sanjana, R. P. (2003): Sweet sorghum: characteristics and potential. International Sorghum Millets News Letter 44: 26-28.

[25] Schittenhelm, S. (2008): Chemical composition and methane yield of maize hybrids with contrasting maturity. - European Journal of Agronomy 29: 72-79.

[26] Steel, R. G. D, Torrie, J. H., Dickey, D. A. (1996): Principles and Procedures of Statistics: A Biometric Approach, 3rd ed. - McGraw-Hill, New York, USA.

[27] Tariq, M., Ayub, M., Elahi, M., Ahmad, A. H., Chaudhary, M. N., Nadeem, M. A. (2011): Forage yield and some quality attributes of millet (Pennisetum americannum L.) hybrid under various regimes of nitrogen fertilization and harvesting dates. African Journal of Agricultural Research 6(16): 3883-3890. 
[28] Vansoest, P. J., Robertson, J. B., Lewis, B. A. (1991): Methods for dietary fiber, neutral detergent fiber and non-starch polysaccharides in relation to animal nutrition. - Journal of Dairy Science 74(10): 3583-3597.

[29] Vasilakoglou, I., Dhima, K., Karagiannidis, N., Gatsis, T. (2011): Sweet sorghum productivity for biofuels under increased soil salinity and reduced irrigation. - Field Crops Research 120: 38-46.

[30] Yosef, E., Carmi, A., Nikbachat, M., Zenou, A., Umiel, N., Miron, J. (2009): Characteristics of tall versus short-type varieties of forage sorghum grown under two irrigation levels, for summer and subsequent fall harvests, and digestibility by sheep of their silages. - Animal Feed Science and Technology 152: 1-11. 